Canadian Studies in Population, Vol. 34.1, 2007, pp. 49-67

\title{
Changes in Economic Status and Timing of Marriage of Young Canadians
}

\author{
Zenaida R. Ravanera \\ Fernando Rajulton \\ Population Studies Centre \\ University of Western Ontario \\ London, Ontario, Canada \\ ravanera@uwo.ca
}

\begin{abstract}
Using the longitudinal panel data collected through the Canadian Surveys of Labour and Income Dynamics (SLID) from 1993 to1998, we examined the hypotheses that (a) higher education delays marriage; (b) labour force participation and earnings of women, like those of men, increase the likelihood of marriage; and, (c) the magnitude of the effects of education and income varies by life course stages of the youth. Analyses were done for men aged 17-19, 2022, and 23-25 and for women aged 15-17, 18-20, and 21-23 at the start of the panel surveys. Our findings confirm our hypotheses, namely, a longer stay in school lowers the risk of marrying while greater economic well-being increases the risk. The results also show that the effects of wages and salaries are strongest among the middle cohorts of men (20-22) and women (18-20) who are at the stage of forming their own independent lives.
\end{abstract}

Key Words: Longitudinal panel study, female labour force participation, marriage timing, life course, school duration 
Zenaida R. Ravanera and Fernando Rajulton

\section{Résumé}

En utilisant les données recueillies par le panel longitudinal de l'Enquête sur la dynamique du travail et du revenu (EDTR) de 1993 à 1998; nous examinons les hypothèses que: a) un plus haut niveau d'éducation délaie le mariage; b) la participation à la main d'œuvre et les gains des femmes, comme ceux des hommes, augmentent la vraisemblance de mariage; et c) que l'importance des effets de l'éducation et des gains varie selon les groupes de cours de vie des jeunes. Nous avons conduit des analyses sur des groupes d'hommes âgés de 17 à 19 ans, de 20 à 22 ans, et de 23 à 25 ans et sur des groupes de femmes âgées de 15 à 17 ans, 18 à 20 ans, et de 21 à 23 au début de l'enquête par panel. Nos constatations confirment nos hypothèses, c'est à dire que des études prolongées diminuent le risque de mariage tandis qu'un niveau économique plus confortable l'augmente. Les résultats démontrent aussi que l'effet des salaires est plus élevé dans la cohorte médiane des hommes (20 à 22 ans) et des femmes (18 à 20 ans) lorsqu'ils sont au stage de former leur indépendance.

Mots clés: Enquête de panel longitudinal, participation des femmes à la main d'œuvre, cours de la vie, durée des études

\section{Theoretical Background}

A most-often cited theory to explain the effects of economic factors on marriage is Becker's hypothesis, the essence of which is captured by this statement from his Treatise on the Family: 'the gain from marriage is reduced by a rise in the earnings and labour force participation of women and by a fall in fertility because a sexual division of labour becomes less advantageous' (Becker 1981: 248). This is often referred to as economic independence hypothesis and implies that labour force participation and the education that facilitates such involvement have negative impact on marriage for women while, presumably, the economic conditions' positive impact continues to hold for men. This is also referred to as specialization and trading model because it assumes that marriage is an exchange transaction based on an implicit gender division of tasks (Oppenheimer, 1997; Sweeney, 2002).

The economic independence hypothesis has been challenged, particularly by Oppenheimer $(1997,2000)$ who points out that the empirical individual-level 
studies do not provide evidence to support the hypothesis. As an alternative to the simple connection between economic independence and marriage, she proposes a more nuanced relationship that takes into account the time spent for schooling and the marriage market. Oppenheimer and Lew (1995:116), for example, propose that "the increasingly achieved nature of women's socioeconomic characteristics introduces some of the same delaying factors into marriage formation that has traditionally existed for men". For both men and women, the relation between marriage timing and labour force involvement is mediated by the time needed to achieve socio-economic characteristics. This means that the effect of education, or specifically, the duration spent in obtaining it, delays entry into marriage for men and women, a career entry hypothesis. Furthermore, in contrast to Becker's hypothesis, they contend that labour force participation and earnings of women could have a positive impact on the timing of marriage. Women's labour force participation, in particular, regular full-time job and long-term employment "provide greater access to more attractive marriage markets, increase a young woman's desirability as a potential mate, or facilitate an earlier marriage than would be possible if it were based on the young man's earning alone" (p. 118).

The contrast between Becker's and Oppenheimer's hypotheses stems from the assumption about the prevailing types of marriage (or family). Becker's isessentially about a complementary or traditional, breadwinner type of family. In contrast, as gleaned from Oppenheimer's $(1997,2000)$ discussion of the disadvantages of gender-based specialization, her proposition assumes that the prevailing, or at the least, the type of marriage aimed at is a symmetrical model, an emerging type of family where couples profit from economic interdependence and husbands engage in housework though not necessarily equal to the wives' unpaid domestic work (Bachrach, Hindin, and Thomson, 2000; Cherlin, 2000).

That family types make a difference is evident from a number of empirical studies that examined the relationship between marriage and labour force participation, earnings, and education. For instance, Blossfeld and his colleagues (1995) hypothesize that the effect of women's level of education on entry into marriage and motherhood depends on the family system prevailing in the country - the more conventional or traditional the family system, the stronger the delaying effect of women's education. Their empirical analyses show that while a longer stay in the educational system does delay entry into marriage (referred to as the institutional effect of education, similar to Oppenheimer's career entry hypothesis), the level of education itself has positive effect in the United States and insignificant or no effect in countries such as Sweden, West Germany, and Hungary (the human capital investment effect) (Blossfeld, 1995). Of the nine countries examined by Blossfeld and colleagues, Becker's economic 
independence hypothesis that implies a negative impact of the level of education on marriage entry is supported only in Italy where the family system is most conventional. Similarly, Tsuya and Mason (1995) show that in Japan, where family types have remained complementary, women with high education and in professional occupations have lower probabilities of marrying.

A corresponding shift in the effect of women's economic status is also evident when studies are made over cohorts. For West Germany, Huinink and Mayer (1995) find that among the 1929 birth cohorts, employed women had lower probabilities of transition to marriage but the probabilities gradually increased over cohorts such that for the 1951- 1961 cohorts, the probabilities had become higher for the employed than for the unemployed. For Canada, using data from the 1995 General Social Survey, Turcotte and Goldscheider (1998) find that, in contrast to women born before 1950, younger women with higher education are more likely to marry. Similarly, Mongeau, Neill, and Le Bourdais (2001) show that work interruptions made marriage more likely among older cohorts of women but among more recent cohorts, uncertainties at work made cohabitation more likely than marriage.

\section{Hypotheses}

In this paper, using prospective longitudinal data, we examine the effect of education, labour force participation, and earnings on the timing of marriage. As the study focuses on young Canadians, our hypotheses would be in line with Oppenheimer's, specifically,

- education of both men and women would delay marriage, and

- labour force participation and earnings of women, like those of men, would increase the likelihood of marriage.

Furthermore, taking a life course perspective, we hypothesize that the magnitude of effects would vary as follows:

- At young ages, it is the career entry hypothesis that would apply; that is, whether or not men or women go for higher education would be the main economic determinant of their probabilities of marrying. The effect of income and labour force participation would be small as most of them would not have as yet established themselves in the labour market. 
- At ages when men and women would have completed postsecondary education, labour force participation and earnings would have a greater impact as these would be major considerations in the active search for partners in the marriage market.

- As men and women grow older, the effects of these economicrelated variables would diminish because many of those motivated mainly by economic factors would have, most likely, already married. For those still unmarried, other reasons for marrying, such as preferences between work and family life, would become more relevant.

\section{Data and Methods}

The Survey of Labour and Income Dynamics, conducted by Statistics Canada, is a longitudinal household survey whose target population is all persons living in Canada excluding residents of Yukon and Northwest Territories, residents of institutions, persons living on Reserves, and full-time members of the Canadian Armed Forces living in barracks (Statistics Canada, 1997). The survey gathers information on people's economic well-being including labour force participation and income, and on other topics such as family-related events (for example, marriage). It collects information for a panel over a period of six years, with a new panel selected every three years. In this study, we use Panel 1, the respondents of which were interviewed twice a year from 1994 to 1999 for information pertaining to the period from 1993 until 1998, with data about the respondents in 1992 as baseline information.

While longitudinal surveys have advantages over cross-sectional surveys, they do have their limitations. Attrition is more severe among the subjects of this study -- young never married men and women are very mobile. Another problem is right-censoring, that is, information gathering is curtailed by the survey dates although estimation through survival analysis, the method used in this study, generally corrects for right censoring. And, left censoring is also a concern, that is, we do not have information on events that happened to the respondents before the survey.

To deal with left-censoring, we use an analytical strategy roughly patterned after Oppenheimer and Lew (1995) that helps us understand the process under study (here, timing of entry in marriage) in spite of censoring. We do our analysis by 3 -year age groups, which allow us to bring a life course perspective. Thus, we could think of the ages 17-19 for men and 15-17 for women as the starting point 
Zenaida R. Ravanera and Fernando Rajulton

of the marriage process (as only about $1 \%$ has already married in 1992, see Table 1). Those among them who would marry in the next six years are the relatively "early marriers". They could be taken as representatives of those whom we missed (or were left-censored) in the two older age groups in our analysis. The men aged 20-22 in 1992 and women aged 18-20 would be marrying in the next 6 years at just about the "right" age, whereas the oldest age groups, 23-25 for men and 21-23 for women, would be the "late marriers".

Table 1

Percentage Never Married in 1992 by Sex and Age Group for Canada

\begin{tabular}{ccccc}
\hline \multicolumn{2}{c}{ Sex } & \multicolumn{4}{c}{ Age Group in 1992 } \\
\hline \multirow{2}{*}{ Men } & $\mathbf{1 7 - 1 9}$ & $\mathbf{2 0 - 2 2}$ & $\mathbf{2 3 - 2 5}$ & Total \\
$\%$ & 98.7 & 89.2 & 64.5 & 84.2 \\
$\mathrm{n}$ & 829 & 753 & 802 & 2384 \\
& & & & \\
Females & $\mathbf{1 5 - 1 7}$ & $\mathbf{1 8 - 2 0}$ & $\mathbf{2 1 - 2 3}$ & Total \\
$\%$ & 99.2 & 89.1 & 61.9 & 83.5 \\
$\mathrm{n}$ & 834 & 745 & 804 & 2383 \\
& & & & \\
\hline
\end{tabular}

Source: SLID Panel 1

By the end of 1992, that is, before the information on events that happened in 1993 were collected through the survey, an equal proportion (16\%) of men aged 17-25 and women aged 15-23 have already been married. As we do not have information on our variables of interests for them, we use the data only for the never married young men and women. Because we confine our study to those who were surveyed in all of the 6 waves, our analysis is based on 1262 men and 1335 women, about 23\% of whom married between 1993 and 1998 (Table 2).

To test the hypotheses outlined above we did Proportional Hazards Modeling for each of the 3-year age groups, using STATA, with age at marriage as our dependent variable. Models were done separately for men and women.

As independent variables, we use Father's education to capture the parental human, social, and financial investment on the respondent's education, and also included the more commonly used variable, Respondent's education. This would test the career entry hypothesis; that is, the higher the father's education, the more likely the respondent would be in school longer (and consequently, 
Changes in Economic Status and Timing

of Marriage of Young Canadians

have higher education), and thus, would be at lower risk of marrying at an early age.

Table 2

Percentage Married in 1998 among the Never Married in 1992 by Sex and Age Group for Canada

\begin{tabular}{ccccc}
\hline \multicolumn{1}{c}{ Sex } & \multicolumn{4}{c}{ Age Group in 1992 } \\
\hline \multirow{2}{*}{ Men } & $\mathbf{1 7 - 1 9}$ & $\mathbf{2 0 - 2 2}$ & $\mathbf{2 3 - 2 5}$ & Total \\
$\%$ & 10.6 & 26.0 & 39.2 & 23.0 \\
Weighted n & 527 & 411 & 324 & 1262 \\
& & & & \\
Females & $\mathbf{1 5 - 1 7}$ & $\mathbf{1 8 - 2 0}$ & $\mathbf{2 1 - 2 3}$ & Total \\
$\%$ & 8.1 & 26.2 & 36.4 & 22.9 \\
Weighted n & 469 & 462 & 404 & 1335 \\
& & & & \\
\hline
\end{tabular}

Source: SLID Panel 1

For indicators of economic inter-dependence, we use Wages and Salaries, and Labour Force Status. As predicted by the hypothesis, for both men and women, these two variables would be positively related to marriage - that is, the higher the salaries, the higher the risk of marriage (and thus, the younger the age at marriage); and, in contrast to the unemployed, those employed would have higher marriage risk.

In the final model, we included Region, as we know that regional differences exist in family formation, with for example, Quebec having higher rates of cohabitation, deemed to delay marriage, compared to the other regions. We considered using Migration status and Ethnicity but there were very few cases of young migrants and visible minority in the sample.

In the modeling, Father's education is considered a time-invariant variable, while all the other variables are time-varying. The modeling also makes use of longitudinal weights to take into account the complexity of sampling procedure and correct for attrition over the six year period. 
Zenaida R. Ravanera and Fernando Rajulton

\section{Results of Analysis}

\section{Results of models with only two variables:}

Table $3 \mathrm{~A}$ and $3 \mathrm{~B}$ show models using only two variables at a time; that is, Father's education, a time invariant variable, paired with each of the other economic-related variables, all of which are time-varying. As can be seen in Model 1 of Table $3 \mathrm{~A}$, men whose fathers had post-secondary education have $67 \%$ lower risk of marrying compared to men whose fathers had elementary education. This difference is significant only for the youngest age group. For women, Model 1 of Table 3B shows that the trend is similar but the ratios do not show up as significant possibly because these two variables (Father's and Respondent's Education) are capturing the same effects. This is seen in Model 2 wherein the effect of Father's education (entered in the model without the Respondent's education) is highly significant for women but only for the youngest age group, which supports the career entry hypothesis.

In Model 2, as expected, Wages and salaries have positive effects for men in the two older age groups. For those aged 20-22 in 1992, the risk of marriage increases by $0.14 \%$ for every $\$ 1000$ increase in wages and salaries. The effect for the 23-25 is positive as well though somewhat smaller. More importantly, the effect of Wages and salaries for women is also positive, as predicted by the economic inter-dependence hypothesis (Model 2, Table 3B). And, following our additional hypothesis, this positive effect is not significant for women aged 2123.

Model 3 shows that those who are not employed are less likely to be married in all age groups of men and for the two older age groups of women.

\section{Results of the full models}

As can be seen in Table 4A that shows the full model for men, the effect of Father's education is highly significant only for the youngest age group. Respondent's education shows somewhat similar effect.

Labour force status no longer shows significant effects in the presence of Wages and Salaries, which is a more refined measure than mere employment. The impact of wages and salaries is significant in the two older age groups, with slightly weaker effect in the oldest age-group.

As mentioned earlier, the lower risk at marriage in Quebec is obvious -- young people are opting more for cohabitation than marriage. As for the other regional 
Changes in Economic Status and Timing

of Marriage of Young Canadians

Table 3A

Models of Relative Risks of Marriage (Hazard ratios and $\boldsymbol{p}$ values) for Males by Age Group for Canada

\begin{tabular}{|c|c|c|c|c|c|c|}
\hline \multirow{3}{*}{ Males } & \multicolumn{6}{|c|}{ Age Group in 1992} \\
\hline & \multicolumn{2}{|c|}{$17-19$} & \multicolumn{2}{|c|}{$20-22$} & \multicolumn{2}{|c|}{ 23-25 } \\
\hline & Hazard & $\mathrm{p}>\mathrm{IzI}$ & Hazard & $\mathrm{p}>\mathrm{IzI}$ & Hazard & $\mathrm{p}>\mathrm{IzI}$ \\
\hline \multicolumn{7}{|l|}{$\begin{array}{l}\text { Model } 1 \\
\text { Father's Education }\end{array}$} \\
\hline \multicolumn{7}{|l|}{ Elementary ${ }^{\circledR}$} \\
\hline Some HS \& HS Graduate & 0.58 & 0.27 & 1.09 & 0.85 & 1.03 & 0.93 \\
\hline Post-Secondary & 0.33 & 0.05 & 1.35 & 0.47 & 0.96 & 0.93 \\
\hline \multicolumn{7}{|l|}{ Respondent's Education } \\
\hline \multicolumn{7}{|l|}{ Less than High School Grad ${ }^{\circledR}$} \\
\hline Graduated High School & 0.97 & 0.18 & 1.01 & 0.66 & 1.03 & 0.14 \\
\hline Non-University Post Sec. & 0.98 & 0.35 & 1.01 & 0.53 & 1.02 & 0.23 \\
\hline University Degree & 1.00 & 0.97 & 1.01 & 0.54 & 1.02 & 0.29 \\
\hline \multicolumn{7}{|l|}{$\begin{array}{l}\text { Model } 2 \\
\text { Father's Education }\end{array}$} \\
\hline \multicolumn{7}{|l|}{ Elementary ${ }^{\circledR}$} \\
\hline Some HS \& HS Graduate & 0.53 & 0.23 & 0.99 & 0.98 & 1.07 & 0.85 \\
\hline Post-Secondary & 0.32 & 0.03 & 1.22 & 0.63 & 0.84 & 0.69 \\
\hline Wages and Salaries $(\$ 1,000)$ & 1.0010 & 0.06 & 1.0014 & 0.00 & 1.0005 & 0.04 \\
\hline \multicolumn{7}{|l|}{ Model 3} \\
\hline \multicolumn{7}{|l|}{ Father's Education } \\
\hline \multicolumn{7}{|l|}{ Elementary ${ }^{\circledR}$} \\
\hline Some HS \& HS Graduate & 0.50 & 0.21 & 0.98 & 0.96 & 1.06 & 0.85 \\
\hline Post-Secondary & 0.39 & 0.02 & 1.28 & 0.57 & 0.76 & 0.51 \\
\hline \multicolumn{7}{|l|}{ Labour Force Status } \\
\hline \multicolumn{7}{|l|}{ Employed All Year ${ }^{\circledR}$} \\
\hline Employed Part-Year & 1.00 & 0.86 & 0.98 & 0.21 & 1.00 & 0.82 \\
\hline Not Employed & 0.93 & 0.05 & 0.94 & 0.03 & 0.94 & 0.01 \\
\hline
\end{tabular}

Source: SLID Panel 1 
Zenaida R. Ravanera and Fernando Rajulton

Table 3B

Models of Relative Risks of Marriage (Hazard ratios and $p$ values) for Females by Age Group for Canada

\begin{tabular}{|c|c|c|c|c|c|c|}
\hline \multirow{3}{*}{ Females } & \multicolumn{6}{|c|}{ Age Group in 1992} \\
\hline & \multicolumn{2}{|c|}{$17-19$} & \multicolumn{2}{|c|}{ 20-22 } & \multicolumn{2}{|c|}{ 23-25 } \\
\hline & Hazard & $\mathrm{p}>\mathrm{IzI}$ & Hazard & $\mathrm{p}>\mathrm{IzI}$ & Hazard & $\mathrm{p}>$ IzI \\
\hline \multicolumn{7}{|l|}{$\begin{array}{l}\text { Model } 1 \\
\text { Father's Education }\end{array}$} \\
\hline \multicolumn{7}{|l|}{ Elementary ${ }^{\circledR}$} \\
\hline Some HS \& HS Graduate & 0.45 & 0.07 & 1.49 & 0.25 & 1.13 & 0.74 \\
\hline Post-Secondary & 0.43 & 0.13 & 0.99 & 0.98 & 1.81 & 0.13 \\
\hline \multicolumn{7}{|l|}{ Respondent's Education } \\
\hline \multicolumn{7}{|l|}{ Less than High School Grad $®$} \\
\hline Graduated High School & 0.96 & 0.08 & 0.98 & 0.28 & 1.03 & 0.35 \\
\hline Non-University Post Sec. & 0.95 & 0.06 & 0.98 & 0.28 & 1.03 & 0.23 \\
\hline University Degree & 0.93 & 0.15 & 1.00 & 0.98 & 1.01 & 0.62 \\
\hline \multicolumn{7}{|l|}{$\begin{array}{l}\text { Model } 2 \\
\text { Father's Education }\end{array}$} \\
\hline \multicolumn{7}{|l|}{ Elementary ${ }^{\circledR}$} \\
\hline Some HS \& HS Graduate & 0.33 & 0.02 & 1.67 & 0.19 & 1.02 & 0.96 \\
\hline Post-Secondary & 0.29 & 0.03 & 1.15 & 0.73 & 1.58 & 0.22 \\
\hline Wages and Salaries $(\mathbf{\$ 1 , 0 0 0 )}$ & 1.0002 & 0.86 & 1.0011 & 0.03 & 1.0002 & 0.62 \\
\hline \multirow{2}{*}{\multicolumn{7}{|c|}{$\begin{array}{l}\text { Model } 3 \\
\text { Father's Education }\end{array}$}} \\
\hline & & & & & & \\
\hline \multicolumn{7}{|l|}{ Elementary ${ }^{\circledR}$} \\
\hline Some HS \& HS Graduate & 0.30 & 0.01 & 1.43 & 0.33 & 0.90 & 0.78 \\
\hline Post-Secondary & 0.27 & 0.02 & 1.00 & 0.99 & 1.41 & 0.36 \\
\hline \multicolumn{7}{|l|}{ Labour Force Status } \\
\hline \multicolumn{7}{|l|}{ Employed All Year ${ }^{\circledR}$} \\
\hline Employed Part-Year & 1.02 & 0.29 & 0.99 & 0.17 & 1.00 & 0.80 \\
\hline Not Employed & 0.96 & 0.15 & 0.96 & 0.05 & 0.96 & 0.05 \\
\hline
\end{tabular}

Source: SLID Panel 1 
differences, we need to find out why Ontario exhibits significantly higher risks of early marriage and British Columbia significantly lower risks of marriage at older ages.

The results of the full model for women (Table 4B) also validate both the main hypotheses of career entry and economic inter-dependence; that is, a longer stay in school (indicated by Father's and Respondent's education) lowers the risk of marrying while indicators of economic well-being increase the risk.

Our additional hypothesis that the effects of these economic considerations would become weaker among the older age group is validated as well. The effect of Labour Force status that shows up as significant when considered on its own (as shown earlier without the wages and salaries) no longer has significant effect in this full model.

\section{Discussion}

\section{Postponement of Marriage}

This study provides insights on possible explanations for the continuing trend of postponement of marriage among young Canadians. The level of education is a main factor simply because going for higher levels of education takes more time. Viewed in terms of transition to adulthood or in terms of career entry, to take one's place in the adult world of work, both men and women must have training and skills that now take a longer duration to complete, which in turn delays family formation. As Beaujot and Kerr (2004: 249) note, half of Canadians aged 25-34 have obtained post-secondary qualification, whereas the average for European countries is about $25 \%$. Going for higher education is most likely facilitated by parental resources but for many, acquiring higher education requires student loans, the period to repay which could also be a contributing factor in the postponement of marriage.

The greater difficulty in entering the work force is another factor that contributes to the postponement of marriage. In recent years, unemployment rates among the young have been higher than among the older age groups, and many of the jobs available to them do not offer long-term security. What this study points to is that the delaying effect of unemployment not only holds for men, as was the case when families were mainly the traditional bread-winner type, but also for women as expectations about families shift from the traditional bread-winner to one of economic inter-dependence, with wives expected to contribute to the economic well-being of the family. 
Table 4A

Full Model of Relative Risks of Marriage (Hazard ratios and $p$ values) for Males by Age Group for Canada

\begin{tabular}{|c|c|c|c|c|c|c|}
\hline \multirow{3}{*}{ Males } & \multicolumn{6}{|c|}{ Age Group in 1992} \\
\hline & \multicolumn{2}{|c|}{$17-19$} & \multicolumn{2}{|c|}{$20-22$} & \multicolumn{2}{|c|}{ 23-25 } \\
\hline & Hazard & $\mathrm{p}>\mathrm{IzI}$ & Hazard & $\mathrm{p}>\mathrm{IzI}$ & Hazard & $\mathrm{p}>\mathrm{IzI}$ \\
\hline \multicolumn{7}{|l|}{ Father's Education } \\
\hline \multicolumn{7}{|l|}{ Elementary ${ }^{\circledR}$} \\
\hline Some HS \& HS Graduate & 0.57 & 0.25 & 0.88 & 0.77 & 1.09 & 0.80 \\
\hline Post-Secondary & 0.36 & 0.04 & 1.08 & 0.86 & 0.68 & 0.39 \\
\hline \multicolumn{7}{|l|}{ Respondent's Education } \\
\hline \multicolumn{7}{|l|}{ Less than High School Grad ${ }^{\circledR}$} \\
\hline Graduated High School & 0.96 & 0.03 & 1.00 & 1.00 & 1.02 & 0.31 \\
\hline Non-University Post Sec. & 0.98 & 0.30 & 1.01 & 0.82 & 1.01 & 0.68 \\
\hline University Degree & 0.98 & 0.70 & 1.00 & 0.97 & 1.00 & 0.83 \\
\hline Wages and Salaries $(\mathbf{\$ 1 , 0 0 0 )}$ & 1.0009 & 0.10 & 1.0013 & 0.00 & 1.0007 & 0.04 \\
\hline \multicolumn{7}{|l|}{ Labour Force Status } \\
\hline \multicolumn{7}{|l|}{ Employed All Year ${ }^{\circledR}$} \\
\hline Employed Part-Year & 1.02 & 0.37 & 1.00 & 0.96 & 1.02 & 0.17 \\
\hline Not Employed & 0.95 & 0.19 & 0.98 & 0.52 & 0.97 & 0.24 \\
\hline \multicolumn{7}{|l|}{ Region } \\
\hline \multicolumn{7}{|l|}{ Atlantic ${ }^{\circledR}$} \\
\hline Quebec & 0.96 & 0.15 & 0.95 & 0.03 & 0.95 & 0.01 \\
\hline Ontario & 1.05 & 0.03 & 0.98 & 0.25 & 1.00 & 0.81 \\
\hline Prairie & 1.02 & 0.28 & 0.98 & 0.19 & 0.99 & 0.55 \\
\hline Brtish Columbia & 1.03 & 0.40 & 1.00 & 0.96 & 0.94 & 0.02 \\
\hline
\end{tabular}

Source: SLID Panel 1 
Changes in Economic Status and Timing

of Marriage of Young Canadians

Table 4B

Full Model of Relative Risks of Marriage (Hazard ratios and $p$ values) for Females by Age Group for Canada

\begin{tabular}{|c|c|c|c|c|c|c|}
\hline \multirow{3}{*}{ Females } & \multicolumn{6}{|c|}{ Age Group in 1992} \\
\hline & \multicolumn{2}{|c|}{$17-19$} & \multicolumn{2}{|c|}{$20-22$} & \multicolumn{2}{|c|}{ 23-25 } \\
\hline & Hazard & $\mathrm{p}>\mathrm{IzI}$ & Hazard & $\mathrm{p}>\mathrm{IzI}$ & Hazard & $\mathrm{p}>\mathrm{IzI}$ \\
\hline \multicolumn{7}{|l|}{ Father's Education } \\
\hline \multicolumn{7}{|l|}{ Elementary ${ }^{\circledR}$} \\
\hline Some HS \& HS Graduate & 0.36 & 0.03 & 1.23 & 0.56 & 0.86 & 0.66 \\
\hline Post-Secondary & 0.35 & 0.06 & 0.88 & 0.76 & 1.25 & 0.56 \\
\hline \multicolumn{7}{|l|}{ Respondent's Education } \\
\hline \multicolumn{7}{|l|}{ Less than High School Grad ${ }^{\circledR}$} \\
\hline Graduated High School & 0.95 & 0.04 & 0.97 & 0.06 & 1.01 & 0.62 \\
\hline Non-University Post Sec. & 0.95 & 0.09 & 0.97 & 0.08 & 1.02 & 0.38 \\
\hline University Degree & 0.91 & 0.09 & 0.99 & 0.46 & 1.01 & 0.78 \\
\hline Wages and Salaries $(\$ 1,000)$ & 0.9998 & 0.91 & 1.0012 & 0.01 & 0.9998 & 0.67 \\
\hline \multicolumn{7}{|l|}{ Labour Force Status } \\
\hline \multicolumn{7}{|l|}{ Employed All Year ${ }^{\circledR}$} \\
\hline Employed Part-Year & 1.01 & 0.54 & 1.00 & 0.70 & 1.00 & 0.86 \\
\hline Not Employed & 0.95 & 0.11 & 0.97 & 0.14 & 0.97 & 0.13 \\
\hline \multicolumn{7}{|l|}{ Region } \\
\hline \multicolumn{7}{|l|}{ Atlantic ${ }^{\circledR}$} \\
\hline Quebec & 0.96 & 0.15 & 0.95 & 0.00 & 0.96 & 0.08 \\
\hline Ontario & 1.03 & 0.16 & 0.99 & 0.61 & 1.00 & 0.95 \\
\hline Prairie & 1.03 & 0.17 & 0.99 & 0.33 & 1.01 & 0.41 \\
\hline Brtish Columbia & 1.02 & 0.49 & 0.97 & 0.11 & 1.02 & 0.25 \\
\hline
\end{tabular}

Source: SLID Panel 1 
Zenaida R. Ravanera and Fernando Rajulton

While this study focused mainly on the economic-related factors, the results hint at other influences at work. Among those marrying at older ages, for example, our analysis shows that economic factors have weaker effects. Possibly at older ages, values become more salient. For example, using Hakim's (2003) categorization of women into home-centered, adaptive, or work-centered on basis of their preferences, we could infer that those who have remained unmarried at even older ages are the work-centered women who would have put larger investment for education and training that delayed marriage even more. Further, their preference for careers might be such that they may not be motivated enough to marry even though their level of economic well-being would have been high enough to "afford" marriage. Another values-related factor pertains to cohabitation. Many of those who have remained unmarried may in fact be in cohabiting unions. While many common-law unions do break up or end in marriage, many unions continue for long duration and are akin to marriage except for the absence of marriage certificate. Presumably, some couples prefer to live in such unions placing less importance to marriage, but others may face constraints such as not being able to reach a stage of economic security that would allow marriage.

\section{Polarization of the Life Course}

While marriage is postponed by many young adults for reasons of longer period of schooling, roughly about $10 \%$ do get married at a young age. As shown by the results, those whose fathers have lower education are more likely to marry young. This points to what keen social observers see as polarization of family life course, which starts early in life and with consequences for the succeeding generation (Bianchi, 2000; Martin, 2000; McLanahan, 2004; Lochhead , 2000; Schulze, H. J. and H. Tyrell, 2002). On one side are those who marry at a young age and would not have acquired the training and skills required to establish themselves in the labour market. They would thus, most likely, lead a life course trajectory that differs from those who have gone on for higher education. Such a trajectory would be characterized by early child-bearing and greater likelihood of experiencing family dissolution and lone parenthood, which in turn have adverse consequences for their children. On the other side are men and women who complete their education, form their family at older age, with the families thus formed likely to consist of dual-earners. This is evidenced by our results showing a positive effect of labour force participation and income for both men and women, the economic inter-dependence hypothesis; pointing to an assortative mating process that pairs men and women with potentials for high earnings. Their later age at marriage, higher education and relatively more stable economic situation could provide protective factors against risks of family 
dissolution. They would thus be in good position to raise children with adequate human, social, and financial resources.

\section{Family Types of Young Couples}

The results of the analysis that conform to Oppenheimer's career and economic inter-dependence hypothesis, rather than Becker's economic independence hypothesis, is an indication that young Canadians are moving away from the traditional, complementary family type. This does not mean however that the marriage of young couples is "symmetrical" or "shared" defined, for example, by Beaujot and Liu (2005) as husbands and wives doing $45-55 \%$ of paid and unpaid work. Families with both husband and wife doing paid work (the dual earners) are becoming more common, but, the sharing of paid and unpaid work even among young couples still shows that the complementary type persists, albeit "weakened" by greater participation of women in paid work and of men in unpaid domestic work. Using data from the 1998 General Social Survey on Time Use, for example, Ravanera, Rajulton, and Turcotte (2003), find that young women spend more time doing unpaid work, particularly, when they form their family. However, to influence the timing of marriage, it is probably sufficient that the expectations of would-be couples tend to be towards the symmetrical type. That is, compared to older cohorts, wives among younger cohorts are expected to contribute to the economic well-being of the family, and husbands are expected to do more of domestic and caring activities; which expectations in turn influence the timing of entry into marriage.

\section{Implications for Program Interventions and Future Research}

Given that economic factors do affect the timing of marriage and that their effects vary by age groups, what possible program interventions might help? To target those who would otherwise marry at young ages, programs that would lessen the effect of disparities in parental resources most especially through better funding for education - not only at the post-secondary but at lower levels as well - might be effective in reducing the effects of polarization. At about the "right age" of marrying, opportunities for employment of both young men and women providing secure sources of income might make for easier transition to marriage and parenthood. And, for everyone, but especially for those who are inclined to delay marriage at later ages (or possibly, forego marriage altogether), what may be needed is to change the perception that family and work are incompatible. In other words, interventions that facilitate the balancing of family and work life such as those related to family benefits and the provision of childcare services should be set in place. 
Zenaida R. Ravanera and Fernando Rajulton

Finally, a related subject of interest is cohabitation. To fully understand marriage, we need to examine cohabitation and its impact on the timing of marriage. The trend in cohabitation has been increasing over cohorts such that among women born in 1976-80, for example, about $78 \%$ of them have already cohabited by 2001 (Ravanera, Rajulton, and Burch, 2005). Wu (1999) suggests that common-law union delays marriage through longer period of pre-marital relationship and less active search for marital partner during the period of cohabitation. Although cohabitation could be seen as the start of forming a family particularly for unions that lead to marriage or to child-bearing, it still differs from marriage in many ways (Ambert, 2005), and thus, the influence of economic factors would differ as well. Cherlin (2000: 135) suggests, for example that in the United States, while it is desirable for women to have earnings, it is still culturally required that men have steady earnings to marry, which requirement presumably does not hold for cohabitation. Thus, we need to examine the influence of economic factors on cohabitation. As cohabitation most often leads to marriage, we need to examine in turn how this relation between cohabitation and economic factors influences marriage. For this analysis, we will need to expand the economic inter-dependence framework for marriage, taking cohabitation as an intermediate stage. We might also need to use other data set, or alternatively, use another technique of analysis as the Survey of Labour and Income Dynamics did not collect data on the age at start of cohabitation though it did gather information as to the marital or union status as of a given year.

\section{Acknowledgement:}

Paper presented at the Conference of the Federation of Canadian Demographers on Longitudinal Studies and Demographic Challenges of the 21st Century Université de Montréal, 18-19 November 2005

\section{References:}

Ambert, Anne-Marrie. 2005. Cohabitation and Marriage: How Are They Related? The Vanier Institute of the Family's website at www.vifamily.ca. Accessed on November 16, 2005.

Bachrach, Christine, Michelle J. Hindin, and Elizabeth Thomson. 2000. The Changing Shape of Ties That Bind: An Overview and Synthesis. In Linda J. Waite (ed) The Ties That Bind: Perspectives on Marriage and Cohabitation. New York: Aldine de Gruyter. Pp. 3-16. 
Changes in Economic Status and Timing

of Marriage of Young Canadians

Beaujot, Roderic and Don Kerr. 2004. Population Change in Canada. Toronto: Oxford University Press.

Beaujot, Roderic and and Jianye Liu. 2005. "Models of Time Use in Paid and Unpaid Work." Journal of Family Issues

Becker, Gary. 1981. A Treatise on the Family. Cambridge; London: Harvard University Press.

Bianchi, Suzanne. 2000. AMaternal employment and time with children: Dramatic change or surprising continuity? Demography 37(4): 401-414

Blossfeld, Hans Peter. 1995. Changes in the Process of Family Formation and Women's Growing Economic Independence: A Comparison of Nine Countries. In H. P. Blossfeld (ed) The New Role of Women: Family Formation in Modern Societies. Boulder: Westview Press. Pp. 3-32.

Cherlin, Andrew J. 2000. Toward a New Home Socioeconomics of Union Formation. In Linda J. Waite (ed) The Ties That Bind: Perspectives on Marriage and Cohabitation. New York: Aldine de Gruyter. Pp. 126-144.

Hakim, Catherine. 2003. A New Approach to Explaining Fertility Patterns: Preference Theory. Population and Development Review 29, 3: 349-374.

Huinink, Johaness and Karl Ulrich Mayer. 1995. Gender, Social Inequality, and Family Formation in West Germany. In Karen Oppenheim Mason and An-Magritt Jensen (eds) Gender and Family Change in Industrialized Countries. Oxford: Clarendon Press. Pp. 168-199.

Lochhead, C. 2000. The trend toward delayed first childbirth: health and social implications. ISUMA: Canadian Journal of Policy Research Autumn: 41- 44.

Martin, S.P. 2000. Diverging fertility among U.S. women who delay childbearing past age 30. Demography 37: 523-33.

McLanahan, S. 2004. Diverging Destinies: How Children are Faring Under the Second Demographic Transition. Demography 41(4): 607-627.

Mongeau, Jael, Ghyslaine Neill and Céline Le Bourdais, 2001. Effet de la précarité économique sur la formation d'une première union au Canada. Cahiers québécois de démographie 30, 1: 3-28. 
Zenaida R. Ravanera and Fernando Rajulton

Oppenheimer, Valerie K. 1997. Women's Employment and the Gain to Marriage: The Specialization and Trading Model. Annual Review of Sociology 23: 431-53.

Oppenheimer, Valerie K. 2000. The Continuing Importance of Men's Economic Position in Marriage Formation. The Changing Shape of Ties That Bind: An Overview and Synthesis. In Linda J. Waite (ed) The Ties That Bind: Perspectives on Marriage and Cohabitation. New York: Aldine de Gruyter. Pp. 283-301.

Oppenheimer, Valerie Kincade and Vivian Lew. 1995. American Marriage Formation in the 1980s: How Important was Women's Economic Independence. In Karen Oppenheim Mason and An-Magritt Jensen (eds) Gender and Family Change in Industrialized Countries. Oxford: Clarendon Press. Pp. 105-138.

Ravanera, Z. R. and F. Rajulton. 2004. Work and Family Life Trajectories of Young Canadians: Evidence from the 2001 General Social Survey. Paper presented at the International Conference on Work-Life Balance across the Life Course. Edinburgh, Scotland. University of Western Ontario Population Studies Centre Discussion Paper 04- 10

Ravanera, Z.R., F. Rajulton, and T.K. Burch. 2005. Cohort and Social Status Differences in Marital Dissolution: Analysis Using the 2001 General Social Survey. Paper presented at the Annual Meeting of the Canadian Sociology and Anthropology Association. London, ON. University of Western Ontario, Population Studies Centre Discussion Paper 05-09

Ravanera, Z., F. Rajulton, and P. Turcotte. 2003. Youth Integration and Social Capital: An Analysis of the Canadian General Social Surveys on Time Use. Youth and Society, 35 (2): 158-182.

Schulze, H. J. and H. Tyrell. 2002. What Happened to the European Family in the 1980s? The Polarization Between the Family and other Forms of Private Life. In Kaufmann, F.X., A. Kuijsten, H.J. Schulze, and K. P. Strohmeier (eds). Family Life and Family Policies in Europe. Vol. 2. New York : Oxford University Press. Pp. 69-119.

Statistics Canada. 1997. SLID Microdata User's Guide. Ottawa: Statistics Canada Catalogue 75M0001GPE. 


\section{Changes in Economic Status and Timing of Marriage of Young Canadians}

Sweeney, Megan. 2002. Two Decades of Family Change: The Shifting Economic Foundations of Marriage. American Sociological Review 67: 132-147.

Turcotte, Pierre and Frances Goldscheider. 1998. The Evolution of Factors Influencing First Union Formation in Canada. Canadian Studies in Population 25, 2: 145-174.

Tsuya, Noriko O. and Karen Oppenheim Mason. 1995. Changing Gender Roles and Below-Replacement Fertility in Japan. In Karen Oppenheim Mason and An-Magritt Jensen (eds) Gender and Family Change in Industrialized Countries. Oxford: Clarendon Press. Pp. 139-167.

Wu, Zheng. 1999. Premarital Cohabitation and the Timing of First Marriage. Canadian Review of Sociology and Anthropology 36, 1: 109-127. 